\title{
Perception of SME's Management Regarding Islamic Banking: A Users vs. Non-users Comparative Analysis
}

\author{
Rabia Umar ${ }^{l}$ \\ Faid Gul ${ }^{2}$
}

\begin{abstract}
Small and medium enterprises (SMEs) are playing a vital role in the Pakistani economy but they are facing a major constraint of lack of finance. The financial instruments being offered by Islamic banks can better meet the financial needs of SMEs but investment in Pakistani SMEs sector is not very high. The current study investigates the difference in perceptions among users and non-users of Islamic banking instruments in Pakistani SMEs sector. This is a primary data based study and its sample size comprises of 110 entrepreneurs of SMEs in the twin cities of Pakistan i.e. Rawalpindi and Islamabad. The study has used independent sample t-test for comparing the difference in the mean values of users and non-users of the Islamic banking products to test the hypotheses of the study. The results of the study show that there is a significant difference in perception among SMEs regarding Shariah compliance by Islamic banks, service quality, business development service and level of awareness regarding Islamic banking instruments due to which Islamic banking is not commonly used by Pakistani's SMEs. This study is helpful to the top management of Islamic banks to devise strategies to clarify the misperception of non-users SMEs management regarding Islamic banking products.
\end{abstract}

JEL Classification: $G 21, M 1, l 26$

Keywords: SMEs, customer perception, Islamic banking, awareness, Shariah compliance, service quality

\section{INTRODUCTION}

SMEs play a vital role in the development of any developing economy like Pakistan as they offer employment generation source and thus help in poverty alleviation by making improvement in people living standards. SMEs also offer job opportunities to minorities like women that are helpful in offering support to their family's financial burden. SMEs sector is contributing $40 \%$ to Pakistan GDP and they are a major source of job creation as more than $82 \%$ of enterprises of Pakistan are falling under the category of SMEs (Economic Survey of Pakistan, 2016-2017). SMEs sector was considered to be one of the fastest growing export sub-sectors of Pakistan before the energy as well as the financial crisis of 2007-2008 but the crisis leads to decline in the growth of this sector. SMEs play an important role in the economy of Pakistan but still, it is facing many constraints for its growth as well as the establishment (Hossain, 1998). Some of the main barriers being faced by SMEs include lack of finance (Beck, Demirgüç-Kunt \& Maksimovic, 2005) policy issues (Hossain, 1998), lack of support by Government (Kureshi, Qureshi, \& Sajid, 2010) and interest rate ceiling (Mohsin, 1995). SMEs are facing the financial obstacles due to banks reluctance in offering credit to them for their growth and development due to lack of financial records being maintained by SMEs, lack of collateral and low credit scoring. According to State bank of Pakistan (2016), 67\% of the finance being extended to SMEs was used to fulfill their working capital requirement in the

1- Bahria University, Islamabad,

2- National University of Modern Languages, Islamabad, E-mail: fgul@numl.edu.pk,faidgul@gmail.com

\begin{tabular}{llll}
\hline JISR-MSSE & Volume 17 & Number 1 & Jan-June 2019 \\
\hline 11
\end{tabular} 
year 2016 that depicts the reluctance by commercial banks to invest in the long run projects of SMEs. There are numerous procedures that are being proposed by policymakers for making improvement in the efficiency of SMEs sector and one of such solutions is offering SMEs with secured equity capital by Islamic mode of financing. Islamic banks are offering numerous modes of financing like Musharakah (partnership), profit-sharing (Mudarabah), cost-plus financing (Murabaha), leasing (Ijarah), forward sale (Bai-salam) and (Istisna). All these modes offered by Islamic can better meet the financial requirements of SMEs due to their different transactional structure by (Ellahi, Bukhari \& Naeem, 2010). Islamic banking is depicting a stable growth over the last few years in Pakistan (SBP report 2016) but their investment in Pakistani SMEs sector is not very high (Hussain \& Al-Ajmi, 2012). State bank of Pakistan (2016) report has shown that conventional banking is having a share of $93 \%$ of total SMEs financing while Islamic banks have only $7 \%$ share in total SMEs financing portfolio which is very low.

\section{PROBLEM STATEMENT}

As an Islamic country, it is commonly expected that people of Pakistan, in general, and managers of SMEs are well aware of Islamic banking. The fact, however, is not according to the common perception. Islamic banking is not very clear to many, especially to the non-users. Therefore, this research is being conducted to assess the difference in perceptions among users and non-users of Islamic banking instruments in Pakistani SMEs sector.

\section{Objectives of the study}

The current study intends to achieve the following objectives:

i. Identify the percentage of SMEs that are utilizing the Islamic banking instruments for their growth and development

ii. To determine factors that motivate SMEs for the adoption of Islamic banking instruments

iii. To assess the difference in perceptions of SMEs towards Islamic mode of financing regarding their religious belief of Islamic bank's Shariah compliance

iv. To assess the difference in perceptions of entrepreneurs towards Islamic mode of financing offered to SMEs sector regarding their knowledge level.

\section{Rationale of the study}

In literature scholars have identified gaps to empirically examine the use of Islamic banking instruments by SMEs sector of developing nations like Pakistan for their growth and development (Rahman \& Rahim, 2007) as Islamic banks can play a significant role in fulfilling the financial needs of SMEs (Ellahi, Bukhari \& Naeem, 2010) and thus they can help them to grow and contribute to Pakistani economy at a higher pace. Sufficient literature is available on assessing the attitude of individual customers towards Islamic finance but insufficient literature is available on assessing corporate customers especially SMEs attitude towards Islamic finance. Comparative studies are conducted on conventional and Islamic banking but are not linked to its role in SME or any other sector of the economy (Gul, Awan \& Ahmad, 2015).In literature, researchers have identified gaps to assess the attitude of SME towards Islamic banking products (Osman \& Ali, 2008; Jaffar \& Musa, 2013; Ahmad \& Haron, 2002). In fact, as per the knowledge of the researcher, there is no study till date that has assessed the factors that are influencing the use of Islamic banking products among SMEs in Pakistan.

42 Jan-June $2019 \quad$ Volume $17 \quad$ Number $1 \quad$ JISR-MSSE




\section{Significance of the study}

The results of this study will be helpful to both the academicians and professionals for better understanding of the difference in perception among users as well as to non-users of Islamic banking product. This study result will also be helpful to top management of Islamic banks in designing their strategies in a manner that would motivate non-users SMEs by clearing their misperceptions regarding Islamic banking products so that they can start using Islamic banking product for their growth and development. This study is one step to make awareness among SMEs as well as small entrepreneurs regarding the real benefit of using Islamic banking products.

\section{LITERATURE REVIEW}

It is acknowledged that economic activity is being diversified with the help of the efficient role of SMEs. Birch (2000) has stated that SMEs are playing a vital role in the facilitation of industrial restructuring in developed economies. Moreover, they are helpful in employment creation as well as wealth and economic growth. Despite their economic contribution, SMEs are facing obstacles as well as challenges. Rodriguez, et al. (2002) has explored that there are three main categories of constraints to be faced by SMEs including policy as well as regulatory framework constraint, managerial capacity constraint and limited access to the financial market constraint. Beyene (2004) states that rules and collateral to be the biggest constraints faced by SMEs in their growth as entrepreneurs could not fulfill minimum requirements that are being set by financial institutions. The study conducted by Hashim (2005) has also supported the findings of the above study and the study has also highlighted some of the weaknesses of SMEs to be lack of capital, inadequate infrastructure, lack of managerial \& technical expertise and limited application of technological \& marketing skills. Deakins and Hussain (1994) stated that banks used to provide short term financing to SMEs as a result of the capacity of SMEs to undertake long term projects and decisions is restricted. Some of the SMEs have sought other mode of financing due to their inability to meet requirements that are being set by financial institutions including personal sources, short term borrowing and equity finance (Cosh \& Hughes, 1994; Mayer, 1984; Scherr et al., 1990). Moreover, entrepreneurs of SMEs can seek informal financial sources for overcoming their finance gaps but research depicts that imperfection in the financial markets is limiting small businesses scope to raise finance and thus they had to rely on banks for financing (Walker, 1989). Eventually, the evolution of Islamic banking can play a significant role in SMEs development as this has emerged to be the fastest growing service that is being acknowledged by Muslim as well as on Muslim entrepreneurs (Iqbal \& Molyneux, 2005).

Islamic finance is a financial service that complies with Shariah-based principles or Islamic laws (Gait \& Worthington, 2008; Karim \& Archer, 2002). Lewis and Algaoud (2001) in their research stated that Islamic finance is based on five main religious features i.e. Riba, haram (nonpermissible) or Halal (permissible, Gharar (speculation), Zakat (purifying alms) and Shariah board (Islamic board). There are differences among Islamic financing and conventional financing (Iqbal \& Mirakhor, 2011) e.g. there is a prohibition of Riba in Islamic banking for avoiding exploitation as well as profiteering. Moreover, Islamic banking is based on firm ethical criteria of Islamic Shariah or law. Hanif and Iqbal (2010) have classified Islamic financing modes in two main categories that include Shariah-compliant products and Shariah-based transactions. In Shariah, compliant products return of financier can be predicted and is fixed within constraints of Shariah like Murabaha, Ijarah, Bai Salam, Istisna, etc.

\begin{tabular}{llll}
\hline JISR-MSSE & Volume 17 & Number 1 & Jan-June 2019 \\
\hline
\end{tabular}


Shariah-based transactions, on the other hand, is based on the principle of risk and profit sharing and return of financier is not predetermined e.g. Mudarabah and Musharikah.

There has been little empirical research done for assessing the business firm's attitude towards Islamic banking instruments as well as finance. Researchers who have worked in this domain include Edris and Almahmeed (1997), Jalaluddin (1999), Ahmad and Haron (2002), Osman and Ali (2008) and Gait and Worthington (2008, 2009). Edris and Almahmeed (1997) have examined the determinants that are used for selecting bank by business firms of Kuwait. The study has taken 304 business firms and findings show that most of the business firm in Kuwait are giving preference to conventional bank over Islamic banks. Moreover, the companies in the study ranked bank size to be the main determinant for bank selection while Islamic banking principles were given the rank of 5 among bank patronage factors in business firms. Jalaluddin (1999) in his study has examined the attitude of 385 firms towards Islamic banking in Australia and results depict that motivating factors for business firms to select Islamic banking include business support, risk sharing level among borrows and lenders and risk default in the traditional system like interest rates.

Ahmad and Haron (20020 have conducted a study in Malaysia to assess the view of 45 corporate customers towards Islamic banking system. The results show that there is a very lower usage rate of Islamic banking products among corporate customers. One of the main factors of lower usage rate is the lower level of knowledge regarding Islamic banking principles as well as Islamic financial system. Khattak (2010) conducted research in Pakistan to assess awareness level of customer about Islamic banking products and results show that $68 \%$ of respondents knew about conventional banking products like current account, savings account but they have little knowledge about Islamic banking products like Mudarabah, Musharikah, etc. Rustam et al. (2011) have examined the perception of corporate customers towards Islamic banking in Pakistan and the study showed that though Islamic banking products are having great potential in corporate sector of Pakistan most of the corporate customers have limited knowledge about products offered by Islamic banks due to lack of marketing strategies of Islamic banks and thus it is not popular in corporate sector. Masood et al. (2014) reported that perception of customer towards Islamic banking is positively linked with awareness level. Khan and Asghar (2012) support the findings by reporting that perception, as well as attitude of customer towards Islamic banking, is linked with awareness level. Chaapra and Bhutto (2013) have found that people's level of knowledge regarding Islamic banking products affect significantly their perception

\section{$\mathrm{H}_{1}$ : Users and non-users SMEs of Islamic banking products differ significantly on knowledge regarding Islamic banking}

Haque et al. (2009) have conducted a study in Malaysia and results show that religiosity levels of customers have a positive relationship with their perception level towards Islamic banking. Subhani et al. (2012) findings also support the above study by stating that religious factors motivate the behavior of customers towards Islamic banking. Haron et al. (1994) findings, however, are dissimilar to above studies as results of the study show that only $40 \%$ of consumers believe that religion is patronage factor towards Islamic banking in Malaysia. $\mathrm{H}_{2}:$ Users and non-users SMEs of Islamic banking products differ significantly on the belief of
Shariah compliance of Islamic banks

44 Jan-June $2019 \quad$ Volume $17 \quad$ Number $1 \quad$ JISR-MSSE


Gait and Worthington (2009) have conducted a study in Libya to assess Libyan business firms attitude towards Islamic mode of finance and the results show that majority of Libyan firms $(72.3 \%)$ were willing to use Islamic finance. According to the research, some of the motivating factors for business firms for using Islamic mode of financing include religion, business support, and unique services. Though conventional banks are giving less preference to SMEs for giving credit due to high-risk factors, yet small business entrepreneurs don't switch towards Islamic banking as they think that bank would be unable to understand their business conditions (Siddiqui, 2008).

$\mathrm{H}_{3}$ : Users and non-users SMEs of Islamic banking products differ significantly on business development services offered by Islamic banks

Rehman and Masood (2012) have conducted a study to assess the perception of customers on selection criteria of Islamic banks and results depict that service efficiency is considered to be significant after shariah compliance.

$\mathrm{H}_{4}$ : Users and non-users SMEs of Islamic banking products differ significantly on quality service offered by the Islamic banks

One of the recent studies conducted by Hove et al. (2014) empirically demonstrate relation among Islamic banking on entrepreneurial motivation as well as firm's superior performance but still, most of SMEs are getting finance from conventional banks rather than Islamic. Though Islamic banking and finance paradigm is being perceived to serve humanity, irrespective of their religion (Khan, 2015), few Muslims let alone non-Muslims are fully aware of solutions being offered by Islamic banking (Echchabi \& Aziz, 2012). This study is one step to assess the perception of SME's managers regarding Islamic banking and to assess the factors that are acting as a hurdle for nonadoption of Islamic banking products even the literature review depicts that almost all of the scholars unanimously agree that Islamic banking instruments are of vital importance for SMEs growth.

\section{RESEARCH METHODOLOGY}

The current study is a primary data based study and it is descriptive in nature as it is being conducted to assess the difference in perception among users as well as to non-users of Islamic banking products of Pakistani SMEs. The current study used a structured questionnaire for collection of data from SMEs. The questionnaire is adapted from the study of Al-Sultan, (1999), Echchabi and Aziz (2012) and Hamid and Nordin (2001). Research is being carried in a noncontrived setting. The questionnaires were distributed to SMEs managers of manufacturing, service or trading sector. The sample size for the current study comprises of 110 entrepreneurs of SMEs in the twin cities of Pakistan i.e. Rawalpindi and Islamabad. Roscoe (1975) has proposed a rule of thumb according to which sample size should be greater than 30 and lesser than 500 for research studies. In order to decrease the margin of error, I have taken a sample size of 110 . The response rate for the current study is $81 \%$. The data gathered from the sample is analyzed through SPSS. In the current study, I had to compare two sample means each of which come from independent group i.e. one group is SME using Islamic banking instruments and other who are not using Islamic banking so in this case independent sample t-test will be useful (Denis, 2018). The current study has used independent sample t-test (by using 95\% significant level) in order to identify the difference among SMEs

\begin{tabular}{llll|l}
\hline JISR-MSSE & Volume 17 & Number 1 & Jan-June 2019 & $\mathbf{4 5}$
\end{tabular}


perceptions on dimensions including the level of knowledge (awareness), Shariah compliance, business development and quality service offered by Islamic banking.

\section{RESULTS AND ANALYSIS}

Descriptive statistics

In order to collect data SMEs from three main sectors were being selected. Following table depicts the percentage of respondents from main sectors i.e. manufacturing, services, and trading.

Table 1: Descriptive statistics

\begin{tabular}{lll}
\hline & Observed N & Percentage \\
\hline Manufacturing & 28 & $31 \%$ \\
Service & 34 & $38 \%$ \\
trading & 28 & 31 \\
Total & 90 & $100 \%$ \\
\hline
\end{tabular}

Percentage of SMEs using Islamic banking

The data is collected from the respondents depict that $37 \%$ of the SMEs are using Islamic banking instrument while the remaining $64 \%$ are non-users of Islamic banking instruments as depicted in the table below

Table 2: SMEs percentage using Islamic banking

\begin{tabular}{lll}
\hline & Observed N & \%age \\
\hline Islamic banking instruments & 33 & $37 \%$ \\
Conventional banking instruments & 37 & 41 \\
Non-users of conventional and Islamic banking & 20 & 22 \\
Total & 90 & $100 \%$ \\
\hline
\end{tabular}

The results depict that lack of finance is one of the hurdles for the growth and development of SMEs in Pakistan as there are $22 \%$ SMEs that are not able to make use of any mode of finance either conventional or Islamic.

\section{Reliability analysis}

In order to check the consistency and validity of research instrument Cronbach's alpha is being found out that is found to be $98.6 \%$ as shown in the following table:

Table 3: Reliability Analysis: Cronbach's Alpha

\begin{tabular}{lll}
\hline Variables & No of item & Cronbach's alpha \\
\hline Awareness & 7 & .86 \\
Shariah Compliance & 8 & .86 \\
Business Dev. Serv. & 7 & .90 \\
Service Quality & 4 & .95 \\
Overall Model & 26 & .986 \\
\hline
\end{tabular}

Nunnally (1978) states that the reliability statistics of .70 or above is considered to be reliable so as the Cronbach's alpha for the all the variables of the current study is above .70 which this shows that the scale is reliable. 


\section{Independent sample t-tests results and analysis}

In order to substantiate the hypothesis independent sample t-test were being conducted in the current study. The results of the tests are given in the tables below:

Table 4: Descriptive Statistics of Users and Non-users

\begin{tabular}{llllll}
\hline & Status & N & Mean & Std. Dev. & Std. Error Mean \\
\hline \multirow{3}{*}{ Awareness } & Users & 37 & 4.4633 & .68711 & .11296 \\
\multirow{3}{*}{ Shariah Compliance } & Non-users & 53 & 2.1887 & .68728 & .09440 \\
& Users & 37 & 4.2278 & .72645 & .11943 \\
Business development & Non-users & 53 & 2.3181 & .72824 & .10003 \\
& Users & 37 & 4.6306 & .96156 & .15808 \\
\cline { 2 - 5 } Quality Service & Non-users & 53 & 1.6069 & .96857 & .13304 \\
& Users & 37 & 3.6419 & .67582 & .11110 \\
& Non-users & 53 & 1.7406 & .55678 & .07648 \\
\hline
\end{tabular}

The group statistics results show that there is a difference in the mean value of both groups. The mean value of users found to be higher on awareness level that shows that SMEs that are aware of the facilities offered by Islamic banking, especially for SME, are using this mode of finance. On the other hand, many SMEs who don't use Islamic banking instruments don't have enough information and awareness regarding the Islamic banking instruments and the way they can help the SMEs in their growth and development. Moreover, results depict that there is the difference in the mean value of SMEs that use Islamic banking instruments due to their belief that they are using Shariah principles while the SMEs that don't use Islamic banking does have the belief that Islamic banks are just the change in the name and in fact they are not Shariah compliant. The results also depict significant differences in the mean value of both the groups with respect to business development services offered by Islamic bank as well as quality services offered by Islamic bank that shows that it is different in the perception of both the groups in these two indicators too.

In order to substantiate hypothesis independent sample test has been conducted and the results are given below:

Table 5: Independent sample test

Levene's Test for Equality of Var. t-test for Equality of Means

\begin{tabular}{lllllll} 
& & $\mathrm{F}$ & $\mathrm{Sig}$. & $\mathrm{t}$ & $\mathrm{df}$ & $\mathrm{Sig}(2)$ tailed) \\
\hline & Equal var. assumed & .066 & .797 & 15.451 & 88 & .000 \\
Awareness & Equal var. not assumed & & & 15.451 & 77 & .000 \\
\hline Shariah & Equal var. assumed & .000 & .997 & 12.253 & 88 & .000 \\
Compliance & Equal var. not assumed & & & 12.259 & 77 & .000 \\
\hline Business & Equal var. assumed & \multirow{2}{*}{1.843} & .178 & 14.615 & 88 & .000 \\
Dev. & Equal var. not assumed & & & 14.635 & 77 & .000 \\
\hline Quality & Equal var. assumed & .003 & .956 & 14.590 & 88 & .000 \\
Service & Equal var. not assumed & & & 14.096 & 67 & .000 \\
\hline
\end{tabular}


The table depicts the F value for the Leven test as this test is being used as a priori for the $\mathrm{t}$ test in order to assess the homogeneity variance. The table depicts that the significance of F-test is greater than .05 for awareness, Shariah, business development and quality service so the assumption of homogeneity of variances is met and thus I will go for further interpretation. The t-test results depict that mean difference among the users and non-users of Islamic banking instruments is found to be significant for awareness, the belief of Shariah compliance, business development as well as quality service. This shows that the SMEs that are not using Islamic banking instruments don't have enough awareness regarding the benefits and availability of the Islamic banking instrument. Thus awareness acts as a factor due to which Islamic banking is not very much popular among the SMEs. Moreover, results depicts that SMEs that are not using the Islamic banking does have the belief that in Pakistan all the banks are using interest-based banking and Islamic banks are just using the name Islamic but in actual their working is not purely Shariah compliant due to which they are not selecting Islamic banks for their growth and development. The results also depict that the SMEs that are using Islamic banking instruments are satisfied with the quality service offered by the Islamic banks while the SMEs that are not using Islamic banking instrument have the belief that Islamic banks are not offering quality services to their clients. Business development is another factor that plays a role in the influence of Islamic banking among SMEs as the result shows that SME that are using Islamic banking instruments are satisfied by its business development service while nonusers are not much attracted by this factor.

\section{How current study results support literature}

The results of the current study support the results of literature. The current study depicts that as there are $22 \%$ SMEs in Pakistan that is not able to make use of any mode of finance and thus lack of finance is one of the major obstacles faced by SMEs. Literature also supports these findings that one of the barriers for growth of SMEs is lack of finance (Hashim, 2005). The current study results depict that the SMEs that are not using Islamic banking instruments; don't have enough awareness regarding the benefits and availability of the Islamic banking instruments. Literature also supports this finding e.g. Ahmad and Haron (2002) state that there is very lower usage rate of Islamic banking products among corporate customers of Malaysia and one of the main factors of lower usage rate is the lower level of knowledge regarding Islamic banking principles. Moreover, Gait and Worthington (2009) state that a business firm's select Islamic banking due to its Shariah compliance and quality service. The current study supports these findings as users of Islamic banking prefer Islamic banking product due to its Shariah compliance and quality service and non-users have perceptions that Islamic banking and conventional banking products have no difference.

\section{CONCLUSION}

The results depict that Islamic banking is less popular among the SMEs in Pakistan due to lack of awareness among the Pakistani SMEs regarding the benefits and features of Islamic banking. Islamic banks need to increase awareness among the SMEs sector of Pakistan regarding the availability of the Islamic banking instruments for their growth and development as many SMEs has the belief that they will not be offered loan by the banks so they never approached the bank. Islamic banks need to create awareness campaigns among the Pakistani SMEs so that they can come to know that they can avail Islamic banking instruments that will be available to facilitate them. Moreover awareness campaigns should clarify the difference in the practices and procedure being used by Islamic banks than the conventional banks so that

48 Jan-June $2019 \quad$ Volume $17 \quad$ Number 12 JISR-MSSE 
SMEs come to know that Islamic banks are interest free banks where SMEs can make use of Mudarabah, Musharakah, Ijarah, and many other instruments that are interest free and that will help them in their growth and development.

The research results show that there is a need to educate Pakistani people that there is nothing common regarding the objectives, principles, mechanisms, operational methods and outcomes between Islamic and conventional banking. Moreover, I think that in Pakistan the products and services being offered by Islamic banks are obsessed with converting the conventional banking products compliant to Shariah due to which many people and SMEs have the belief that it is just the change in the name. Thus Islamic banks should offer some new products and services and along with that, they should educate the people regarding how their products are Shariah compliant. Islamic banks should start these educational campaigns among the SMEs sector of Pakistan in order to educate them and in order to increase their growth and development with the help of Islamic instruments.

\section{REFERENCES}

Abu-Hussain, H., \& Al-Ajmi, J. (2012). Risk management practices of conventional and Islamic banks in Bahrain. The Journal of Risk Finance, 13(3), 215-239.

Ahmad, N. \& Haron, S. (2002). Perceptions of Malaysian Corporate Customers Towards Islamic Banking Products and Services. International Journal Of Islamic Finance Services, 3(1), 13- 29.

Beck, T., Demirgüç-Kunt, A. S. L. I., \& Maksimovic, V. (2005). Financial and legal constraints to growth: Does firm size matter?. The Journal of Finance, 60(1), 137-177.

Berry, A., Rodriguez, E., \& Sandee, H. (2002). Firm and group dynamics in the small and medium enterprise sector in Indonesia. Small Business Economics, 18(1), 141-161.

Beyene, A. (2004). Enhancing the competitiveness and productivity of small and medium scale enterprises (SMEs) in Africa: an analysis of different roles of national governments through improved services. Africa Development, 27(3), 30-56

Birch, D. L. (2000). The job generation process. Small business: Critical Perspectives on Business and Management, 2, 431-465.

Chhapra, I. U., \& Bhutto, S. (2013). An Empirical Investigation on Perception of Post-Graduate Students towards Islamic Finance in Islamic Republic Of Pakistan. Asian Journal of Research in Banking and Finance, 3(12), 68.

Cosh, A. D., \& Hughes, A. (1994). Innovation activity and performance in SMEs. British Enterprise in Transition: Growth Innovation and Public Policy in the small and medium sized enterprise sector, 1999.

Deakins, D., \& Hussain, G. (1994). Financial information, the banker and the small business: a comment. The British Accounting Review, 26(4), 323-335.

Denis, D. J. (2018). SPSS Data Analysis for Univariate, Bivariate, and Multivariate Statistics. John Wiley \& Sons.

Echchabi, A., \& Aziz, H. A. (2012). Empirical investigation of customers' perception and adoption towards Islamic banking services in Morocco. Middle-East Journal of Scientific Research, 12(6), 849-858.

Edris, T. A. \& Almahmeed, M.A. (1997). Services considered important to business customers and determinants of bank selection in Kuwait: a segmentation analysis. International Journal of Bank Marketing, 15(4), 126-133 
Ellahi, N., Bukhari, T. A., \& Naeem, M. (2010). Role of Islamic Modes of Financing for Growth of SMEs: A Case Study of Islamabad City. International Journal of Academic Research, 2(6).

Gait, A., \& Worthington, A. (2008). An empirical survey of individual consumer, business firm and financial institution attitudes towards Islamic methods of finance. International Journal of Social Economics, 35(11), 783-808.

Gul, F., Awan, M.B., \& Ahmad, I. (2015). Do Islamic Banks Financially Perform Better than Conventional Banks? A Comparative Study of Pakistani Banks. NUML International Journal of Business \& Management, 10(2), 27-50.

Hanif, M. \& Iqbal, A.M. (2010). Islamic Financing and Business Framework: A Survey, European Journal of Social Sciences, 15 (4), 475-489.

Haque, A. K. M., Osman, J., \& Ismail, A. Z. (2009). Factor influences selection of Islamic banking: a study on Malaysian customer preferences. American Journal of Applied Sciences, 6(5), 922-928.

Haron, S., Ahmad, N., \& Planisek, S. L. (1994). Bank patronage factors of Muslim and non-Muslim customers. International Journal of Bank Marketing, 12(1), 32-40.

Hasan, S. A., Subhani, M. I., \& Osman, M. (2012). Consumer criteria for the selection of an Islamic Bank: Evidence from Pakistan

Hashim, M. K. (2005). Small and Medium-sized Enterprises in Malaysia: Problems and Prospects. UUM Press.

Hossain, N. (1998). Constraints to SME Development in Bangladesh. Institutional Reform and the Informal Sector, University of Maryland, College Park.

Hove, P., Sibanda, K., \& Pooe, D. (2014). The impact of Islamic banking on entrepreneurial motivation, firm competitiveness and performance in South African small and medium enterprises. Mediterranean Journal of Social Sciences, 5(15), 165.

Iqbal, M., \& Molyneux, P. (2016). Thirty years of Islamic Banking: History, Performance, and Prospects. Springer.

Iqbal, Z., \& Mirakhor, A. (2011). An Introduction to Islamic Finance: Theory and Practice (Vol. 687). John Wiley \& Sons.

Jaffar, M. A., \& Musa, R. (2013). Determinants of attitude towards Islamic financing among Halal-certified micro and SMEs: A proposed conceptual framework. International Journal of Education and Research, 1(8), 1-10.

Jalaluddin, A. (1999). Attitudes of Australian small business firms and financial institutions towards the profit/loss sharing method of finance.

Karim, R. A. A., \& Archer, S. (Eds.). (2002). Islamic Finance: Innovation and Growth. Euromoney books and AAOIFI

Khan, F. (2010). How 'Islamic' is Islamic Banking?. Journal of Economic Behavior \& Organization, 76(3), 805-820.

Khan, H. N., \& Asghar, N. (2012). Customer awareness and adoption of Islamic Banking in Pakistan. Interdisciplinary Journal of Contemporary Research in Business, 3(9), 359-366.

Khattak, N. A. (2010). Customer satisfaction and awareness of Islamic banking system in Pakistan. African Journal of Business Management, 4(5), 662-671.

Kureshi, N., Qureshi, F., \& Sajid, A. (2010). Current health of quality management practices in service sector SME: A case study of Pakistan. The TQM Journal, 22(3), 317-329.

Lewis, M. K., \& Algaoud, L. M. (2001). Islamic banking. Books. 
Masood, S., Rehman, S., \& Rehman, C. A. (2014). Cognizing customer awareness and perception of Islamic banking products in Pakistan. International Journal of Operations and Logistics Management, 3(4), 322-336.

Meyer-Krahmer, F. (1984). Recent results in measuring innovation output. Research Policy, 13(3), 175-182.

Ministry of Finance Government of Pakistan. (2018). Retrieved from http://www.finance.gov.pk/survey_1617.html

Osman, M. R., \& Ali, H. (2008, October). Exploring Muslim entrepreneurs' knowledge and usage of Islamic financing. In Seminar Keusahawanan Islam II Peringkat Kebangsaaan, Universiti Malaya (Vol. 15).

Rahman, A. R. A., \& Rahim, A. (2007). Islamic microfinance: a missing component in Islamic banking. Kyoto Bulletin of Islamic Area Studies, 1(2), 38-53.

Rehman, A., \& Masood, O. (2012). Why do customers patronize Islamic banks? A case study of Pakistan. Qualitative Research in Financial Markets, 4(2/3), 130-141.

Roscoe, J.T. (1975). Fundamental Research Statistics for the Behavioural Sciences, 2nd edition. New York: Holt Rinehart \& Winston.

Rustam, S., Bibi, S., Zaman, K., Rustam, A., \& Haq, Z. U. (2011). Perceptions of corporate customers towards Islamic banking products and services in Pakistan. The Romanian Economic Journal, 41, 107-123.

Scherr, F. C., Sugrue, T. F., \& Ward, J. B. (1993). Financing the small firm start-up: Determinants of debt use. The Journal of Entrepreneurial Finance, 3(1), 17-36.

Siddiqui, A. (2008). Financial contracts, risk, and performance of Islamic banking. Managerial Finance, 34(10), 680-694.

SMEDA. (2018). Retrieved from https://smeda.org/index.php?option=com_content\&view $=$ article $\&$ id $=7$ : state-of-smes-inpakistan\&catid $=15$

Walker, D. (1989). Financing the small firms. Small Business Economics, 1(4), 285-96 


\section{Appendix}

\section{Questionnaire}

Objective: The questionnaire is designed to study "Assessment of difference in Perceptions Regarding Islamic Banking among SMEs". The information you provide will help us better conduct the research so please try to answer the question as honest as possible. The information you provide will be kept strictly confidential.

Name (Optional)

Organization Name

Designation

Please answer the following questions, using the criteria below by encircling the appropriate number.

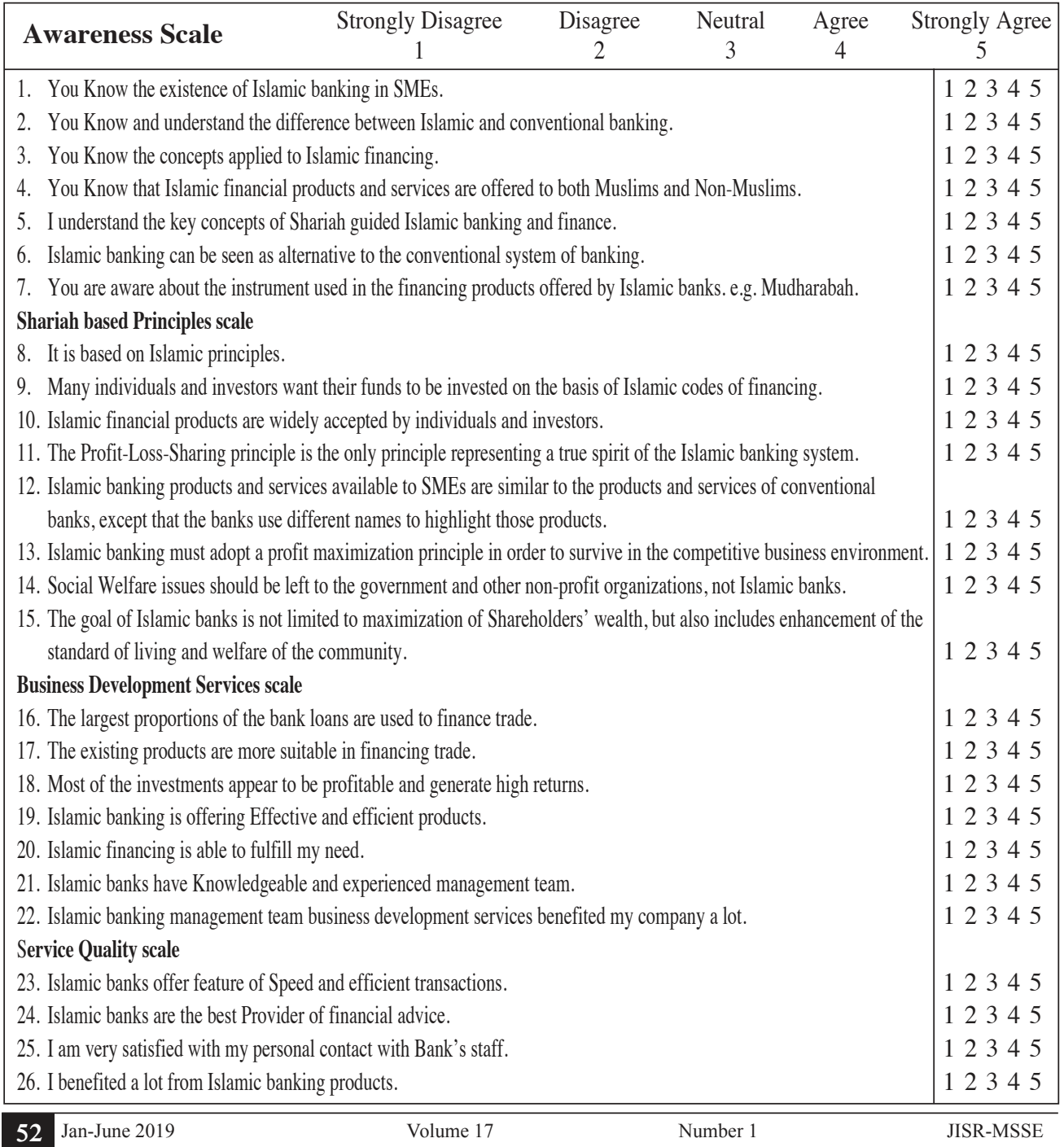

